\title{
Values and Dispositions of Omani Novice Teachers as Perceived by School Principals and Assistant Principals
}

\author{
Fawzia Al Seyabi ${ }^{1}$ \\ ${ }^{1}$ College of Education, Sultan Qaboos University, Sultanate of Oman \\ Correspondence: Fawzia Al Seyabi, College of Education, Sultan Qaboos University, Sultanate of Oman. E-mail: \\ fawzia@squ.edu.om
}

Received: July 8, 2020

Accepted: September 27, $2020 \quad$ Online Published: October 8, 2020

doi:10.5539/hes.v10n4p25

URL: https://doi.org/10.5539/hes.v10n4p25

\begin{abstract}
Equipping teacher candidates with values and dispositions has become an important part of the conversation about effective teaching and teacher preparation programs are increasingly expected to integrate dispositions in their agenda. The purpose of the present study is two-folded. It aims at investigating the kind of dispositions of novice Omani teachers as perceived by school principals and assistant principals. It also aims to identify the type of factors that affect the shaping of novice teachers' dispositions/values. Interviews were conducted with ten school principals and five assistant principals from various public schools in two different directorates of education in Oman. Data of the interviews were analyzed qualitatively by identifying the most emerging themes in terms of the most and least developed dispositions as well as factors shaping them. Findings revealed that dispositions related to ambition and flexibility were highly observed among novice teachers while dispositions related to sense of belonging and commitment and responsibility were less observed. The study also showed that there was a range of factors shaping the development of novice teachers dispositions ranging from broader macro factors such as how the society views a teacher and the appointment situation in Oman to more micro institutional factors such as the huge demands of the job and the type and level of support that schools provide to novice teachers. The paper makes recommendations relevant to both teacher preparation programs and the Ministry of Education.
\end{abstract}

Keywords: dispositions, novice teachers, Oman

\section{Introduction}

Equipping teachers and teacher candidates with values and dispositions has become an important part of the conversation about effective teaching, and teacher preparation programs are increasingly expected to integrate dispositions in their agenda. Today, professional dispositions have been recognized as an integral part of the expected outcomes of teacher education (Cochran-Smith, 2005; Al-Rawashdeh, Ivory \& Writer, 2017). Having extensive knowledge of the subject matter and the competencies to teach it effectively is not adequate if teachers do not have the "right" dispositions to help them perform their job effectively.

During the past two decades, issues related to teacher dispositions have gained significant attention in the field of teacher education (Dottin, 2009; Freeman, 2007). Dozens of studies have been published to investigate dispositions such as identifying the most important dispositions for the teaching profession (Carroll, 2007; Huntley, 2004), and assessment tools used to measure them (Lang and Wilkerson, 2008; Dottin, 2009; Edick et.al., 2006; Karges-Bone \& Griffin, 2009; Notar et.al, 2009). Moreover, a quick look at the websites of various universities shows that higher education programs in these universities have identified their list of dispositions that they believe are crucial for the teachers they are preparing.

Moir and Gless (2001) found that the early experiences of new teachers serve to set the norms and standards that will guide them throughout their careers. Once they graduate and join the teaching profession, novice teachers are expected to perform a variety of tasks and at the same time adjust to new environments with new roles. For many, this could be daunting and could create a "transition shock" (Michel, 2013). Research is needed to look closely at novice teachers' dispositions and the factors that shape their making. As far as the researcher is aware, there is yet no research that looked at this important dimension in the preparation of teachers in the Omani educational context. Moreover, since the first few years of teaching are the most important it is imperative that universities and schools work together to ensure new teachers have the knowledge, skills and support necessary 
to help them succeed in their first placements. It is hoped that the present paper would shed light on this important issue and make recommendations for both schools and universities.

In this study, the perceptions of a total of 15 school principals and assistant principals were collected regarding the kind of dispositions that characterize novice Omani teachers. The research questions that guided this study were:

1) What are the most and least developed dispositions of novice Omani teachers as perceived by school principals and assistant principals?

2) What type of factors affect the shaping of these dispositions as perceived by school principals and assistant principals?

\section{Literature Review}

Dispositions, as defined in Thorndike-Barnhart Dictionary are the qualities that characterize a person as an individual: the controlling perceptual (mental, emotional, spiritual) qualities that determine the person's natural or usual ways of thinking and acting. Definitions of dispositions in psychology emphasize that they are attributes that are more person-centred. Dispositions are not behaviours. The latter, indeed are symptoms of the former. Usher, Usher and Usher (2003) explain that dispositions reflect the perceptual "state" of the teacher at the time of his or her actions. They further add that "to understand the dynamics of teacher behaviour and its effectiveness we must direct our attention to the nature of the practitioner's personal meanings or dispositions (p. 2).

A look at the literature also shows that the terms dispositions, attitudes, beliefs and even personality traits are sometimes used interchangeably, often to describe an orientation toward students and the teaching profession. Usher et al. maintain that the term "disposition" serves well to displace the more confusing term, "belief". Teacher dispositions are more than just beliefs but rather the tendency for those beliefs to be put into practice in the classroom (Costa \& Kalik, 2000, cited in Wenzel and Roberts, 2014) and in the broader school environment.

According to the National Council for Accreditation of Teacher Education (NCATE), dispositions are the values, commitments, and professional ethics that influence behaviours toward students, families, colleagues and communities and affect student learning, motivation and development as well as the educator's own professional growth. They are guided by beliefs, perceptions and attitudes. Beteram and Fascal (2002) add another dimension to their understanding of dispositions and emphasize that they are not context-free. To them, dispositions are behaviours or traits that are environmentally sensitive; they could be fostered, refined, and weakened by an individual's interactions with others around them. Moreover, dispositions are affected by cultural, historical, and social factors that act as mediators in the development of dispositions (Obara, 2009). Since 2002, NCATE has required teacher preparation programs to incorporate dispositions in their programs and to provide evidence that standards for professional dispositions are being met (NCATE, 2008).

The concept of dispositions in teacher preparation programs is so wide that different schools of education in different parts of the world chose to focus on different specific aspects and/or manifestations of the term (Varol, 2011; Walker, 2019). In the School of Education, New York University, Tobias, Fan and Bang (2008) describe how their institution focuses on developing two key dispositional dimensions of quality teachers: teaching efficacy and caring. Bercaw, Colby and Payne (2012) describe the experiences of two American universities in California in developing their set of dispositions. State University West chose to focus on five dispositions in their teacher preparation program: appreciating human diversity, believing that all children can learn, commitment to continuous self-directed learning and reflection, demonstrating pride in the education profession and use of democratic values. Efforts are made at the program level to connect course work to these dispositions. In State University East, the elementary teacher preparation program adopted three dispositions: a commitment to meeting the needs of all children, commitment to reflective practice and commitment to professional and ethical practice.

In their literature review, Hillman, Rothermel, and Scarano (2006) identified several dispositions that are important for being a professional and effective teacher. Some of the dispositions highlighted were self-efficacy, high expectations, an ethic of caring, sensitivity toward others, and reflective capability. These were described as critical components of being an effective teacher.

The complexity of the concept of dispositions in the arena of teacher education is partially caused by the lack of a set of common stable descriptors. This lack of a common set is not strange given that there are multiple ideological perspectives, conflicting political views on teacher preparation, and possible misalignment between stakeholders (e.g., university versus schools) (Seidel and Whitcomb, 2015). Beyer (2002) also maintains that 
unlike the "technical-rational" approach normally followed in the teaching of knowledge and skills, the teaching of dispositions in teacher preparation programs is not straightforward as it is affected by "social, philosophical and political understandings".

Whitsett, Roberson, Julian, and Beckham (2007) conducted a study to investigate first year teachers' self-reported levels of development on a set of dispositions. Based on the results of their study, the most developed dispositions as identified by novice teachers are treating others with respect and fairness, demonstrating a willingness to learn from others, and demonstrating active concern for the progress of all learners. The least developed dispositions, on the other hand, were acknowledging the importance of family, community, school, cultural and other contexts to learning, and demonstrating willingness to reach and repertoire.

To date, very few studies have focused on the sources of teachers' dispositions and the factors that help shape them (Tennant, et al., 2019; Levin and He, 2008; Mueller \& Hindin, 2011). Levin and He (2008) conducted a study of 94 prospective teachers using an instrument that they developed to measure the sources of teacher candidates' belief systems. Based on participants' self-reporting of the sources for each of their beliefs regarding different aspects of teaching, researchers identified three main categories: (a) family background and their K-12 education, (b) observations and teaching experiences during their field experiences, and (c) coursework in their teacher education program. Findings of the study revealed that $28 \%$ of the participants attributed their beliefs to their experiences as K-12 students. This was followed by factors related to participants' individual teaching experiences during their field placements, the observations they had made, and the workshops that they had attended and from their personal religious beliefs. The researchers also found that most participants reported their beliefs had their foundation in the explicit curriculum they received in their course work in the teacher preparation programs they had.

In a similar study, Mueller and Hindin (2011) examined the experiences that influence pre-service teacher candidates' dispositions. The researchers presented two scenarios for the participants on their study to analyze, one focusing on inclusion and the other focusing on cultural stereotypes. The researchers found that overall, most candidates reported that they drew upon material learned in their education classes when responding to both scenarios, especially classes that addressed topics related to inclusion and diversity. They also found that candidates' field experiences have mixed impacts on their situational responses to the scenarios. Only about half of the candidates drew on experiences from the field when responding to both scenarios and these were often described as negative. The researchers warned that when facing negative experiences, these may stunt candidates' developing dispositions rather than support them. They further suggest that these experiences get presented and discussed in coursework and that they get used as reflection tools to help teacher candidates develop and maintain social consciousness.

\section{Method}

The study at hand presents the results of a preliminary investigation that aimed to identify school principals' perceptions of the dispositions that characterize novice Omani teachers especially that no previous study was conducted on the topic in the Omani educational context. It is hoped that data gathered in the present preliminary study will help towards the building of further research tools for a national study on the same topic funded by an internal grant from Sultan Qaboos University, Oman.

The design chosen for this study was a qualitative method to provide a vivid description of the perceptions of school principals and assistant principals regarding the dispositions of novice teachers appointed at their schools. One of the merits of qualitative research is that it emphasizes the meanings and experiences of the study participants about the topic of the study, which helps explain how people interpret their environment and experiences and what meaning they place on those experiences (Daher, 2017).

\subsection{Sample}

The sample of the study consisted of 10 school principals and 5 assistant principals of Cycle 2 schools (grades 5 to 10 in Oman's public school system) from two educational governorates in Oman: Muscat and Batinah South. Selection of participants was mainly based on availability and willingness to be included in the study. The participants were all Omani and their years of experience in their administrative positions as principals and assistant principals ranged from four to fifteen years. Eleven of the participants were females and four were males. However, as far as the present study is concerned, no attempt was made to compare participants' responses based on their gender. 


\subsection{Instrument}

Individual semi-structured interviews were conducted with the fifteen participants. An interview, as a qualitative data collection tool, is often considered a suitable method to have access to people's perceptions, definitions of situations and construction of reality (Punch, 2009). These were conducted in Arabic. The qualitative data were analyzed to identify any themes that had emerged within each of the questions, with these themes providing the framework for subsequent analysis and discussion.

\section{Results}

\subsection{Novice Teachers' Dispositions}

To answer the first research question, the interviewed school principals and assistant principals were asked to give a general evaluation of the dispositions of novice teachers appointed in their schools. In case there were no newly appointed teachers in these schools for the last few years, the participants were still able to draw on their previous experiences with novice teachers.

To help make the answer to the question more direct and specific, participants were asked to indicate what dispositions were more observed among novice teachers and which were least observed.

\section{Most developed dispositions}

Table 1. Novice teachers' most developed dispositions as perceived by school principals and assistant principals

\begin{tabular}{|c|c|}
\hline Most observed dispositions & Examples of statements provided by interviewees \\
\hline Ambition & $\begin{array}{l}\text { - "Better skills in general." } \\
\text { - "Are qualified in terms of subject knowledge." } \\
\text { - "New teachers seem to be more ambitious than } \\
\text { older or more experienced teachers." } \\
\text { - "More willing to take in positions." }\end{array}$ \\
\hline Flexibility & $\begin{array}{l}\text { - "They like to try out new methods and techniques." } \\
\text { - "More willing to embrace change." }\end{array}$ \\
\hline Willingness to learn & $\begin{array}{l}\text { - "More desire to attend new training courses } \\
\text { and professional development sessions." } \\
\text { - "Up to date." } \\
\text { "Better technology related skills and better } \\
\text { implementation of these skills in the classroom." }\end{array}$ \\
\hline Care and communication with students & - "Might be more likeable by students, especially teenagers." \\
\hline
\end{tabular}

As can be seen in the table, the strengths of novice teachers in terms of their dispositions, as expressed by interviewed participants centred around four main areas: ambition, flexibility, willingness to learn and communication with students.

Most of the interviewed principals and assistant principals believed that novice teachers are generally more ambitious than their older colleagues working in the same schools as they "care to ask more about their career paths as teachers" and are also "more willing to take in new administrative positions vacant in the school". Another facet of ambition is the willingness to learn. Novice teachers are more ready to attend training courses and professional development sessions and they like to keep up to date with the latest developments in their fields. They are also more willing to try out new methods in their teaching and experiment with new ideas and innovations. More specifically, according to the interviewed principals and assistant principals, novice teachers show more willingness to learn about technology and technological programs and tools and show more efficiency in using these in their classrooms.

Another disposition that is more often observed in novice teachers is their flexibility. According to the interviewed principals and assistant principals, novice teachers show more flexibility in accepting new ideas, not only ideas regarding new teaching methods -as reported earlier- but also new projects at the school or directorate level. As stated by one school principal, novice teachers are more ready to embrace change.

Another interesting finding of the study was that novice teachers were also reported to be successful in showing care towards students, understanding their mindsets, and relating to them, especially at the personal level. Several interviewed participants narrated incidents where they felt novice teachers, given the proximity of their age to the student group- especially teenage students, were more able to communicate with some students and solve some student issues. 


\section{Less developed dispositions}

Table 2. Novice teachers' less developed dispositions as perceived by school principals and assistant principals

\begin{tabular}{ll}
\hline Less observed & Examples of statements provided by interviewees \\
professional dispositions &
\end{tabular}

The first aspect reported by interviewed participants addressed novice teachers' attitude towards the profession and their sense of belonging to the job in general and the school community in particular. According to interviewed participants, novice teachers are more likely to complain about the huge demands of the job and are less content about the conditions of the school. They also show less initiative and are quick to say "no" to extra lessons or school activities as they normally expect financial rewards for duties that are not listed in their job descriptions. One interviewed principal stated, "There are a few novice teachers who care more for their rights but tend to question their obligations" and "take time to see that teaching is much more than a job to get paid for". Another reported observation was that some novice teachers do not show the same level of respect for authority and tend to be more questioning than the more experienced teachers who are more familiar with both rules and norms of working in a school environment.

Another area reported by interviewed participants was related to novice teachers' responsibility and sense of commitment to the job. Some novice teachers find it difficult to take full responsibility for their actions and are reluctant to take on extra work responsibilities. This includes covering classes for absent colleagues, which shows the distance they feel from the community of practice of their subject matter, represented in the other teachers of the same subject in their schools. As some interviewed participants put it: There are a few novice teachers who are not equipped with the strength and the resilience to carry out the responsibilities of the job.

Punctuality and timeliness were another area. Some novice teachers as observed by interviewed participants are less punctual when arriving to school and their classes. They also tend to miss classes more often than the more experienced teachers especially if they get appointed in teaching positions outside their home regions. Another common observation among school principals is that novice teachers who come from other regions often need to leave early on the last day of the week and special arrangements are made at the school administration to facilitate this process for them.

As for communication and rapport, novice teachers were reported to exhibit more individualism and less desire to communicate with other teachers and with the school administration in general. They were also less likely to participate in social gatherings outside work hours -such as home visits, compared with the more experienced teachers.

Novice teachers were also reported to have more issues with classroom management, especially in dealing with behavioural issues and in their ability to identify their relationships with students in more "acceptable" terms as 
some tended to share their personal problems and concerns with students, perhaps in an attempt to get closer to them.

\subsection{Factors Shaping Novice Teachers'Dispositions}

The second research question aimed to gather school principals and assistant principals' views on the type of factors that may contribute to the shaping of novice teachers' dispositions. Qualitative analysis of interview data revealed that factors could be categorized into two types: Macro/social factors, and micro/institutional factors.

\section{Macro/Social factors}

Interviewed school principals and assistant principals mentioned a number of social factors that shape teachers' dispositions. One especially important factor is how society views a teacher and the value of a teacher in the outside community. They believe that the role of a teacher has been marginalized in society, which affects new teachers' self-esteem and their sense of job satisfaction. Some interviewees also talked about the negative messages in social media, especially when comparisons are made between the salaries and benefits of a teacher in Oman with those provided in other countries. A school principal pointed out that "at this young age, new teachers find it difficult to decide what works for us and what doesn't". Al Kindi (2006) in his evaluative study of the competencies of beginning teachers in Oman pointed that practising teachers, when compared with pre-service ones- are more likely to consider a change of career, if the opportunity allows, in response to the negative attitudes they start to develop because of the work overload.

Another important factor mentioned by most interviewees is the appointment situation in Oman where -based on the teaching needs of the Ministry of Education- most new teachers get appointed in other governorates or educational directorates rather than their hometowns/regions. Whereas in some cases teachers have no choice but to live in the towns/villages where they were assigned, others decide to commute for not less than two hours daily to get from their hometowns to their schools. What this has created is "lack of stability", and "lack of belonging to the school environment" as most teachers believed they were only there for a temporary time. The interviewed school principals and assistant principals asserted that this has always affected teacher motivation and commitment. While this area has been researched widely in other educational contexts (Lock, 2008), there is scarcely any research on the influence of this on Omani teachers. This is an area where more research is highly needed.

Besides, Oman, like many other countries in the world is facing a financial dilemma with the decline in oil prices and the limited non-oil revenues that aid the national economy. The difficult financial situation, according to the interviewed school principals and assistant principals has played a big role in teacher motivation and dispositions. Many new teachers tend to complain about the low salary and the reductions in the material and office supplies provided by the Ministry of Education.

\section{Micro-Institutional factors}

Besides the broader societal and financial factors that affect novice teachers' dispositions, there are more specific institutional factors that may contribute towards our understanding of the nature of teacher dispositions. To start with, the interviewed school principals and assistant principals mentioned the huge demands of the job and the pressure it creates on teachers. The school has high/unrealistic expectations for what a novice teacher can do given that they are new to the profession. That is why new teachers are easier to feel that the workload is both unreasonable and unmanageable.

Another factor is the amount of support that a school/school principal can provide to a novice teacher. Some new teachers find it hard to accept or understand the rules and regulations stipulated by the Ministry or directorate, mainly because "they were not there when these regulations were made so they do not know the background".

One school principal believed that the leadership model adopted by the school administration: the school's vision and mission might be hard for novice teachers to appreciate and understand. Another mentioned factor was the lack of cooperation of the directorates of education and or MoE (e.g. maintenance issues) which affects teachers' motivation and hence their dispositions.

Another range of institutional factors was more related to the teacher preparation programs/institutions that novice teachers graduated from. The interviewed participants believed that preparation in teacher education institutions is more focused on knowledge and skills and less on values and dispositions. Furthermore, during the admission stage, selection criteria do not consider the type of values and dispositions that teachers are expected to exhibit on the job. A number of interviewed principals and assistant principals also commented that teaching might not have been teachers' first preference, which affects their motivation as well as their resilience in the job. 


\section{Discussion}

The present study investigated the perceptions of 15 school principals and assistant principals of the kind of depositions that novice teachers appointed at their schools exhibit, both strongly and weakly, especially when compared with the more experienced teachers. Findings of the study revealed that novice teachers show strength in certain dispositions such as ambition, flexibility and willingness to embrace change, willingness to learn and more appreciation of lifelong learning, and communication with students. Novice teachers were shown generally to be more willing to embrace new ideas such as innovative projects.

The present study revealed that novice teachers had stronger dispositions towards professional development and life-long learning. This result is not strange considering that novice teachers are fresh graduates and they might still feel the need to develop their knowledge and skills in different areas related to the teaching profession. Varol (2011) in his surveying of the perceptions of 118 teacher educators from 11 NCATE accredited teacher education institutions in the State of Florida also found that willingness to learn received a high score among novice teachers.

Novice teachers were also reported to show more readiness to embrace change. Previous research showed that veterans show more resistance towards change (Snyder, 2017; Goodson et al., 2006), compared with novice teachers who might show more enthusiasm and positivity towards implementing mandated curriculum reform (Dilkes et al., 2014). Instead of embracing an utter change, the teachers are more likely to merge their original teaching strategy with a new one, producing a somewhat compromised option ( $\mathrm{Li} \& \mathrm{Lu}, 2019)$. Novice teachers, being young in the field are still in the process of developing their beliefs and they are hence more likely to be influenced by new circumstances.

Novice teachers showed care towards their students. Although the literature identifies several aspects and manifestations of teacher care, Pang (2005) asserts that care is demonstrated when teachers take a genuine interest in getting to know their students beyond the academic setting and develop reciprocal relationships with them, an aspect which participants of the study reported to be a characteristic in the novice teachers they had. Add to that, showing care towards students and having knowledge of them as individuals, also referred to as relational knowledge (Webb and Blond, 1995, cited in Tobias, 2008) is one of the characteristics of teaching efficacy, and there is a significant body of research that supports the importance of a caring teacher both in the classroom and in the school at large (Noddings, 2005; Bruce and Stellern, 2005). Moreover, previous research on the effect of teacher age revealed that students expected younger teachers to be more able to build student-teacher rapport (Joyel and Wilson, 2015) compared with older teachers.

As for the least developed dispositions among novice teachers, one main finding in the present study concerns their collaboration and rapport with others. A previous study of Omani teachers revealed that although novice teachers were aware of the importance of cooperation with others to improve pupils' performance, their actual performance in this regard was lagging (Al Kindi, 2006). Whitsett et al. (2007) as presented in the literature review- found a similar result. Willingness to reach and repertoire was found among the least developing dispositions among beginning teachers in their study. Despite what the literature says about peer support and its importance to beginning teachers as they join their new school environments, it seems that novice teachers still find it difficult to take initiative and outreach to others when the need arises. This should have implications on the level and kind of mentoring programs that novice teachers receive especially in their initial year in the service.

Oliver (2005) writes about three types of isolation that new teachers often feel in their new school environments. The first is psychological; new teachers often miss the kind of support they received in their pre-service programs and find few opportunities to dialogue with other teachers. The second is physical. New teachers are sometimes physically isolated especially when given physically isolated classrooms or teachers' rooms to use. The third type of isolation is social, which is often caused by hesitation to provide support by the more experienced teachers in fear of it being interpreted as interference, or hesitation to ask for support by new teachers themselves in fear of it being interpreted as an admission of failure and incompetence. This may have serious implications on the kind of support that novice teachers receive from the school community.

Another less observed disposition concerns novice teachers' classroom management skills. This result is very much congruent with the literature, where classroom management was found to be among the biggest challenges of novice teachers (Achinstein and Barret, 2004; Sozen, 2018; Sadika and Akbulut, 2015; Hughes, 2017). Differences in knowledge and expertise between experienced and novice teachers mean that while the former can maintain a broad awareness of classroom scenes and events, novices can be easily overwhelmed by the complexity of incoming information (Tsui 2003; Wolf et al. 2016) and tend to use a more "interventionist" 
classroom management style compared with the more experienced teachers (Martin \& Baldwin, 1994).

As for the other observations made by the study participants concerning novice teachers' lack of punctuality and commitment, it is quite possible that these are all manifestations of the transition shock that a lot of novice teachers experience as they deal with the complexities, ambiguities and uncertainties associated with the job.

Interviews with the study participants have also revealed that there are various factors that affect novice teachers' dispositions. These were grouped into macro/social factors and micro/institutional factors. Obara (2009) suggested that the mediators of disposition development could be either hindrances or affordances depending on a) intrapersonal perceptions, preferences, and career commitment; b) interpersonal resources such as mentoring; and c) extra-personal resources such as institutional funding. Regardless of their type, mediators of dispositions can be considered as products of personal, social, historical, and cultural factors.

In their first few years of service, especially their first year, novice teachers experience a case of shock as they try to balance their roles as new teachers still learning how to teach and developing their professional identity in a new school context (Farrell, 2016). This becomes more complicated when novice teachers find themselves appointed in schools not in their regions, as they then have to cope with homesickness, anxiety and frustration. They often find the demands of the job too overwhelming, which affects their dedication level and feelings of belonging to the school and its culture. This might explain the coping problems that the study participants mentioned and the tendency of some new teachers to "complain" easily about the overwhelming demands of the job. Senom et al. (2013) in their nationwide large-scale study to explore novice teachers' socialization problems found that in terms of problems concerning the school community, the novice teachers in the study reported that they were struggling with the burden of teaching assignments and clerical works, new leadership roles, high expectations, lack of support and guidance, isolation and school politics.

The current appointment situation in Oman, where the majority of fresh graduates get appointed in other governorates and most often in remote areas, was reported as another factor affecting teachers' dispositions. There are normally special challenges associated with rural teaching but several studies in the literature have found that current teacher preparation courses in universities do not equip students with the skills and knowledge to teach in rural areas (Lock, 2008; Moir and Gless, 2001). This is an area that still needs further research.

As for institutional factors, one big aspect that the study participants reported is the kind of preparation that novice teachers in their schools receive before appointment and whether there was focus on teachers' values and dispositions. A lot of research shows that the attitudes and dispositions of pre-service teachers can be influenced by the type of preparation they get and although the change might not be dramatic, it can lead to more reflective and effective teachers. Once they are in the field, the kind of experiences they go through in their early years serve to set the norms and standards that will guide them throughout their careers (Moir and Gless, 2001). Thus, as the first few years of teaching are the most important it is imperative that universities and schools work together to ensure new teachers have the knowledge, skills and support necessary to help them succeed in their first placements.

\section{Recommendations}

Several recommendations can be made for teacher preparation programs. First, the ethical values and dispositions of the job should be integrated in the different courses that student teachers take in their teacher preparation programs, and in the student teaching course. As part of these courses, students can get to work on projects that get them to see this aspect in real school environments. Second, it is important that colleges conduct programs and workshops that address values and dispositions regularly, preferably organized by student teachers themselves so that they take a more active part. In the student teaching course, student teachers have to see how every objective of the lesson is loaded with values and dispositions. During their field experiences, student teachers have to be exposed to the different roles/tasks that are expected of them such as supervising a class, supervising an extracurricular activity, meeting parents, solving students' problems...etc so that they get a real taste of the demands of the job.

At the school setting, the ability of novice teachers to cope with their work should be considered a collective responsibility in schools rather than the fate of the individual teacher. The support that novice teachers get from their mentors, senior teachers and more experienced teachers at the school is especially important to cope with the shock of the transition from a protected educational setting - where they only are responsible for their education and well-being - to a school setting, where they also are responsible for the education and well-being of others (Caspersen and Raaen, 2014), and from "peripheral participation" to "full participation" (Lave \& Wenger, 1991). Besides colleagues' support, administrators' support, including that of the school principal is an important part of teacher induction. School principals are encouraged to stop comparing novice teachers with the 
more experienced ones and to learn ways to deal with the new generations of novice teachers, and- as one interviewed school principal put it- to embrace their mindsets and to involve them in the school community. Future research can focus on professional socialization of teachers in the Omani educational context as this area is still lacking.

\section{References}

Achinstein, B., \& Barret, A. (2004). (Re)Framing classroom contexts: How new teachers and mentors view diverse learners and challenges of practice. Teachers College Record, 106(4), 716-746. https://doi.org/10.1111/j.1467-9620.2004.00356.x.

Al Kindi, A. (2006). An evaluation of the initial scientific field teacher education programme in the colleges of education, Oman. $\mathrm{PhD}$ thesis.

Al-Rawashdeh, A., Ivory, J., \& Writer, J. (2017). Evaluating the Dispositions of Teacher Education Candidates: A Place for Self-Assessment. Journal of Educational and Psychological Studies, 11(4), 749-761. https://doi.org/10.24200/jeps.vol11iss4pp749-761

Bercaw, L., Summers, D., Colby, S., \& Payne, M. (2012). Mirror images: teacher candidates' perceptions of disposition development. Action in Teacher Education, 34(5-6), 514-525. https://doi.org/10.1080/01626620.2012.729481

Beyer, L. (2002). The politics of standards and the education of teachers. Teaching Education, 13, 305-316. https://doi.org/10.1080/1047621022000023280

Bruce, M., \& Stellern, J. (2005). Building a caring community in teacher education. The Teacher Educator, 41(1), 34-51. https://doi.org/10.1080/08878730509555370

Carroll, D. (2007). Developing dispositions for ambitious teaching. Journal of Educational Controversy, 2(2). Retrieved from http://cedar.wwu.edu/jec/vol2/iss2/7/

Caspersen, J. \& Raaen, F. D. (2014). Novice teachers and how they cope. Teachers and Teaching: Theory and Practice, 20(2), 189-211. https://doi.org/10.1080/13540602.2013.848570

Cochran-Smith, M. (2005). The new teacher education: For better or worse. American Educational Research Journal, 34(7), 3-17. https://doi.org/10.3102/0013189X034007003

Daher, M., Carré, D., Jaramillo, A., Olivares, H., \& Tomicic, A. (2017). Experience and meaning in qualitative research: A conceptual review and a methodological device proposal. Forum Qualitative Social Research, $18,24$.

Dilkes, J., Cunningham, C., \& Gray, J. (2014). The new Australian curriculum, teachers and change fatigue. Australian Journal of Teacher Education, 39(11). http://dx.doi.org/10.14221/ajte.2014v39n11.4

Dottin, E. (2009). Professional judgment and dispositions in teacher education. Teaching and Teacher Education, 25, 83-88. https://doi.org/10.1016/j.tate.2008.06.005

Edick, N., Danielson, L., \& Edwards, S. (2006). Dispositions: Defining, aligning and assessing. Academic Leadership: The Online Journal, 4(4). Retrieved from htps://scholars.fsu.edu/alj/vol4/iss4/4

Goodson, I., Moore, S., \& Hargreaves, A. (2006). Teacher nostalgia and the sustainability of reform: The generation and degeneration of teachers' missions, memory and meaning. Educational Administration Quarterly, 42(1), 42-61. https://doi.org/10.1177/0013161X05278180

Hillman, S., Rothermel, D., \& Hotchkiss, G. (2006). The assessment of preservice teachers' dispositions. The Teacher Educator, 41(4), 234-250. https://doi.org/10.1080/08878730609555386

Hughes, M. (2017). Elevated dispositions for teacher leadership. Servant Leadership: Theory \& Practice, 4(2), 85-97.

Joyel, S., \& Wilson, J. (2015). Professor age and gender affect student perceptions and grades. Journal of the Scholarship of Teaching and Learning, 15(4), 126-138. https://doi.org/10.14434/josotl.v15i4.13466

Michel, H. (2013). The first five years: Novice teacher beliefs, experiences, and commitment to the profession. UC San Diego. Retrieved from https://escholarship.org/uc/item/3cq6954m

Mueller, M., \& Hindin, A. (2011). An analysis of the factors that influence pre-service elementary teachers' developing dispositions about teaching all children. Issues in Teacher Education, 20(1), 17-34.

Karges-Bone, L., \& Griffin, M. (2009). Do they have the right dispositions? Teacher education in the new 
conceptual Age. SRATE Journal, 18(2), 27-33.

Lang, S., \& Wilkerson, J. (2008). Measuring Teacher Dispositions with Different Item Structures: An Application of the Rasch Model to a Complex Accreditation Requirement. Paper presentation at the annual meeting of the American Educational Research Association, New York.

Lave, J., \& Wenger, E. (1991). Situated learning: Legitimate peripheral participation. Cambridge: Cambridge University Press. https://doi.org/10.1017/CBO9780511815355

Levin, B., \& He, Y. (2008). Investigating the content and sources of teacher candidates' personal practical theories (PPTs). Journal of Teacher Education, 59(1), 55-68. https://doi.org/10.1177/0022487107310749

Lock, G. (2008). Preparing teachers for rural appointments: Lessons from Australia. Rural Educator, 29(2), 24-30. https://doi.org/10.35608/ruraled.v29i2.470

Martin, N., \& Baldwin, B. (1994). Beliefs Regarding Classroom Management Style: Differences Between Novice and Experienced Teachers. Paper presented at the Annual Conference of the Southwest Educational Research Association, San Antonio, TX.

National Council for Accreditation of Teacher Education (2008). Professional standards for the Accreditation of Teacher Preparation Institutions. Retrieved from http://www.ncate.org/ /media/Files/caep/accreditation-resources/ncate-standards-2008.pdf?la=en

Noddings, N. (2005). The challenge of care in schools. Teachers College Press, New York, NY, USA.

Notar, C., Riley, G., Taylor, P. W., Thornburg, R. A., \& Cargill, R. L. (2009). Dispositions: Ability and assessment. International Journal of Education, 1(1), 1-14. https://doi.org/10.5296/ije.v1i1.133

Obara, D. (2009). Processes of disposition development in K-5 teachers. PhD dissertation. University of Nevada Las Vegas.

Oliver, J. (20015). A comparison of the perceptions between novice and veteran teachers about the teaching profession in elementary and middle schools in Sevier County, Tennessee. Unpublished PhD dissertation. East Tennessee State University.

Pang, V. O. (2005). Multicultural education: A caring-centered reflective approach. NewYork: McGraw Hill.

Punch, K. F. (2009). Introduction to research methods in education. Los Angeles, London, New Delhi, Singapore, Washington: SAGE Publications Ltd.

Sadika, F., \& Akbulut, T. (2015). An evaluation of classroom management skills of teachers at high schools. Procedia - Social and Behavioral Sciences, 191, 208-213. https://doi.org/10.1016/j.sbspro.2015.04.539

Seidel, K., \& Whitcomb, J. (2015). Exploring novice teachers core competencies. International Perspectives on Education and Society, 27, 197-238. https://doi.org/10.1108/S1479-367920140000027010

Senom, F., Abd Razak, Z., \& Shanina, S. A. (2013). Novice teachers' challenges and survival: Where do Malaysian ESL teachers stand? American Journal of Educational Research, 1(4), 119-125. https://doi.org/10.12691/education-1-4-2

Snyder, R. (2017). Resistance to change among veteran teachers: Providing voice for more effective engagement. NCPEA International Journal of Educational Leadership Preparation, 12(1).

Tobias, R., Fan, B., \& Bang, H. (2008). Measuring the developing dispositions of pre-service and beginning teachers. Paper presented at the Annual Meeting of the American Educational Research Association. New York City.

Tsui, A. (2003). Understanding expertise in teaching: Case studies of second language teachers. Cambridge: Cambridge University Press. https://doi.org/10.1017/CBO9781139524698

Varol, V. (2011). Teacher educators' perceptions about teacher dispositions. PhD dissertation. Florida State University.

Usher, L., Usher, M., \& Usher, D. (2003). Nurturing five dispositions of effective teachers. Second National Symposium on Educator Dispositions. Eastern Kentucky University, Richmond, KY.

Walker, T. (2019). Development of a teacher dispositions framework. A Dissertation Presented in Partial Fulfillment of the Requirements for the Degree Doctor of Education: Higher Educational Leadership. Louisiana Tech University.

Whitsett, G., Roberson, T., Julian, K., \& Beckham, L. (2007). First year teachers' reported levels of functioning 
on selected professional dispositions. Education, 128(1), 95-102.

Wenzel, A., \& Roberts, J. (2014). Coaching teacher dispositions. Association for Middle Level Education.

Tennant, L., Stringer, P., Riddlebarger, J., Dickson, M., \& Kennetz, K. (2019). Emergence of Professional Identities of Novice Emirati Teachers. Australian Journal of Teacher Education, 44(9), 44-61. https://doi.org/10.14221/ajte.2019v44.n9.3

\section{Copyrights}

Copyright for this article is retained by the author(s), with first publication rights granted to the journal.

This is an open-access article distributed under the terms and conditions of the Creative Commons Attribution license (http://creativecommons.org/licenses/by/3.0/). 